\title{
ANALISIS KEMAMPUAN PEMECAHAN MASALAH MATEMATIS SISWA MELALUI IMPLEMENTASI POGIL DITINJAU DARI GAYA KOGNITIF
}

\author{
Tias Estiningrum ${ }^{1}$, Destia Wahyu Hidayati ${ }^{1}$, Arie Wahyuni ${ }^{1}$ \\ ${ }^{1}$ Universitas Ivet, Jalan Pawiyatan Luhur IV No.17, Semarang, Indonesia \\ Email: tiasesty213@gmail.com \\ Email: destia281289@gmail.com \\ Email: ariewahyuni20@gmail.com
}

\begin{abstract}
Abstrak
Penelitian ini bertujuan untuk menganalisis kemampuan pemecahan masalah matematis siswa melalui implementasi model POGIL ditinjau dari gaya kognitif Field Independent(FI)dan Field Dependent(FD). Penelitian ini merupakan penelitian campuran atau mix method. Subjek kelas penelitiannya adalah kelas XI Pemasaran 1 SMK Negeri 2 Semarang, ditentukan dengan menggunakan teknik purposive sample. Pengumpulan data dilakukan dengan tes dan wawancara. Hasil tes GEFT digunakan untuk menentukan subjek penelitian berdasarkan gaya kognitif, dipilih 2 siswa bergaya FI dan 2 siswa bergaya FD. Data kualitatif dianalisis dengan melakukan 3 tahapan yaitu reduksi data, penyajian data dan menarik kesimpulan sedangkan data kuantitatif dianalisis menggunakan program Quest. Hasil penelitian sebagai berikut 1) Kemampuan pemecahan masalah siswa FI pada tahap memahami masalah, merencanakan penyelesaian, melaksanakan perencanaan masalah hingga memeriksa kembali seluruhnya berkategori baik. 2) Kemampuan pemecahan masalah siswa FD pada tahap memahami masalah berkategori cukup, sedangkan tahap merencanakan penyelesaian, melaksanakan penyelesaian masalah hingga memeriksa kembali berkategori kurang.
\end{abstract}

Kata Kunci: Kemampuan Pemecahan Masalah, Gaya Kognitif

\begin{abstract}
This study aims to analyze students' mathematical problem solving abilities through the implementation of the POGIL model in term of the Field Independent (FI) and Field Dependent (FD) cognitive styles. This research is a mixed research or mix method. The subject of the research class was Class XI Marketing 1 SMK Negeri 2 Semarang, determined using purposive sample technique. Data collection is done by tests and interviews. GEFT test results are used to determined research subject based on cognitive style, selected 2 FI style students and 2 FD style students. Qualitative data were analyzed by carrying out 3 stages : data reduction, data presentation and drawing conclusion while quantitative data analysed using the Quest program. The result of study are as follow 1) The problem solving ability of FI students the stage of understanding of problem, planning a solution, carrying out a problem planning to re-checking all of the categorized as good, 2) The problem solving ability of FD students at the stage understanding the problem is categorized as sufficient, while the stage of planning the solution, carrying out the problem solving up to re-checking the category is deficient.
\end{abstract}

Keywords: Problem Solving Ability, Cognitive Style

\section{PENDAHULUAN}

Menurut Suryadi (2012), matematika merupakan ilmu pengetahuan yang lebih menekankan pada kemampuan pemecahan masalah dan kemampuan berpikir matematik, sedangkan menurut Hidayati (2017) matematika merupakan salah satu mata pelajaran yang wajib diajarkan di Sekolah. Tidak jarang ditemui kendala yang dialami oleh siswa berkaitan dengan pemecahan masalah dalam pembelajaran matematika. Zevenbergen (2004 : 107 - 108) berpendapat bahwa dalam memecahkan masalah perlu memiliki pemahaman dan pengetahuan yang memadai serta mempunyai berbagai 
macam strategi untuk dapat dipilih saat menghadapi permasalahan yang berbeda-beda. Sehingga yang menjadikan kesalahan bagi siswa dalam mempelajari matematika, mereka hanya menghafal rumus rumus yang diberikan tanpa memahami apa yang dipelajari dan mengerti tentang pengetahuan yang diperoleh ketika belajar matematika. Ungkapan tersebut sependapat dengan Hendriana (2012: 25) yang menurutnya siswa cenderung hanya menghafalkan konsep-konsep matematika dan definisi tanpa memahami maksud isinya. Salah satu tujuan yang dicapai dalam pembelajaran matematika adalah agar siswa memiliki kemampuan pemecahan masalah yang meliputi kemampuan memahami masalah, merancang model matematika, menyelesaikan model dan menafsirkan solusi yang diperoleh (BSNP, 2006: 346). Tujuan tersebut menempatkan pemecahan masalah menjadi bagian dari kurikulum matematika yang penting. Siswa harus sering diberikan soal-soal yang butuh pemahaman dalam menyelesaikannya, latihan memecahkan masalah akan membuat siswa belajar mengorganisasikan kemampuannya dalam menyusun strategi yang sesuai untuk menyelesaikan masalah dan pemecahan masalah mendorong siswa untuk mendekati masalah autentik, dunia nyata secara sistematis. (Jacobsen, Eggen dan Kauchak, 2009 : 255).

Berdasarkan hasil wawancara dengan Loesy Rahmawati selaku guru pengampu mata pelajaran Matematika kelas XI jurusan Pemasaran SMK Negeri 2 Semarang pada hari Senin tanggal 28 Mei 2018, beliau mengutarakan permasalahan yang dialami oleh sebagian siswa di kelas tersebut adalah kesulitan dalam menyelesaikan beberapa soal yang diberikan, mereka cenderung mengalami kebingungan dalam memilih strategi yang tepat untuk memecahkan masalah tersebut hingga diperoleh jawaban yang benar. Hasil Penilaian Tengah Semester (PTS) genap memperlihatkan bahwa nilai yang diperoleh pada Mata Pelajaran Matematika hanya 54\% yang mencapai KKM yang telah ditetapkan yaitu 75 atau dari 3 kelas jurusan Pemasaran dengan total 108 siswa, terdapat 59 siswa yang memperoleh nilai diatas KKM. Proses menerima, memahami dan mengolah informasi dari suatu pelajaran yang diberikan oleh guru untuk kemudian digunakan dalam menyelesaikan masalah matematis setiap siswa tentunya berbeda. Dengan perbedaaan tersebut setidaknya guru memiliki berbagai macam gaya, seperti gaya belajar dan gaya kognitif. Menurut Wahyuni (2017) gaya belajar membutuhkan langkah-langkah dalam proses belajar sedangkan menurut Arifin (2015:15) menjelaskan bahwa perbedaan cara siswa dalam memperoleh, mengolah dan memproses informasi yang didapatnya dinamakan gaya kognitif.

Desmita (2009 : 145) berpendapat bahwa gaya kognitif adalah karakteristik individu dalam menggunakan fungsi kognitif (berpikir, mengingat, memecahkan masalah, dan sebagainya) yang bersifat konsisten dan lama.Terdapat banyak dimensi dari gaya kognitif yang dikembangkan oleh para ahli yang dapat membedakan individu, dimensi yang paling penting adalah Field Independent dan Field Dependent (Salameh, 2011: 189). Gaya kognitif digolongkan menjadi 2 yaitu gaya kognitif Field Independent (FI) dan Field Dependent (FD). Siswa dengan gaya kognitif Field Independent (FI) cenderung lebih memilih belajar secara individu, menanggapi permasalahan dengan baik, tidak bergantung pada orang lain dan dapat menerima pelajaran secara cepat (memfokuskan diri pda materi secara rinci). Sedangkan siswa dengan gaya kognitif Field Dependent (FD) cenderung lebih memilih belajar secara kelompok dan sering berinteraksi dengan siswa lain atau guru, memerlukan penguatan yang bersifat ekstrinsik. (Woolfolk, 2006 : 187). Model pembelajaran yang digunakan dalam penelitian ini adalah model Process Oriented Guided Inquiry Learning (POGIL) karena model ini berpusat pada siswa dan proses pembelajaran. Menurut Hanson (2004), tujuan dari penerapan model pembelajaran Process Oriented Guided Inquiry Learning (POGIL) adalah mengembangkan keterampilan proses pada area belajar (learning), berpikir (thinking) dan menyelesaikan masalah (problem solving), membuat siswa berpartisipasi aktif dalam pembelajaran, meningkatkan interaksi antarsiswa dan interaksi antar guru dan siswa, menumbuhkan sikap positif terhadap matematika, mengaitkan pembelajaran dengan teknologi informasi, dan mengembangkan ketrampilan komunikasi. 
Berdasarkan uraian di atas, permasalahan dalam penelitian ini adalah sebagai berikut : 1) Bagaimana deskripsi kemampuan pemecahan masalah matematis siswa kelas XI Pemasaran 1 dengan gaya kognitif Field Independent?, 2) Bagaimana deskripsi kemampuan pemecahan masalah matematis siswa kelas XI Pemasaran 1 dengan gaya kognitif Field Dependent?

\section{METODE PENELITIAN}

Jenis Penelitian ini merupakan penelitian campuran atau mix method yaitu penggabungan dari penelitian kualitatif dan kuantitatif. Penelitian ini dilaksanakan di SMK Negeri 2 Semarang, selama 3 hari yaitu tanggal 31 Mei - 1 Juni 2018 dan tanggal 7 Juni 2018. Populasinya adalah seluruh kelas XI Jurusan Pemasaran, dengan subjek kelas penelitiannya adalah kelas XI Pemasaran 1, penetapan subjek kelas penelitian dilakukan dengan menggunakan teknik purposive sample yaitu teknik penentuan sampel dengan pertimbangan tertentu dan mewakili sifat atau karakteristik dari suatu populasi (Sugiyono, 2010:85). Teknik pengumpulan data menggunakan tes dan wawancara terbuka dengan tujuan subjek penelitian dapat mengemukakan pendapat atau menyampaikan ide-ide sesuai pemikiran mereka. Instrumen yang digunakan adalah soal tes tertulis kemampuan pemecahan masalah yang telah diuji validitas, reliabilitas, tingkat kesukaran dan daya bedanya menggunakan program Quest yang kemudian diperoleh 3 soal yang layak digunakan untuk penelitian, tes GEFT yang terdiri dari 3 kelompok soal dengan kelompok soal pertama berisi 7 soal, kelompok soal kedua dan ketiga berisi 9 soal dan pedoman wawancara yang terdiri dari 4 pertanyaan pokok terkait proses pemecahan masalah. Hasil tes GEFT digunakan untuk menentukan subjek penelitian berdasarkan gaya kognitif dengan ketentuan skor 0 - 11 termasuk dalam siswa FD dan skor 12-18 termasuk dalam siswa FI. Berikut Tabel Daftar Subjek Penelitian yang terpilih berdasarkan skor tes GEFT :

Tabel 1. Daftar Subjek Penelitian

\begin{tabular}{cl}
\hline Kode & Gaya Kognitif \\
\hline A09 & Field Dependent \\
A10 & Field Dependent \\
A12 & Field Independent \\
A13 & Field Independent \\
\hline
\end{tabular}

Keabsahan data sangat perlu dilakukan agar data yang dihasilkan dapat dipercaya dan dipertanggungjawabkan secara ilmiah. Teknik yang digunakan peneliti untuk memeriksa keabsahan data adalah teknik triangulasi metode yang dilakukan dengan cara membandingkan data dari subjek secara tertulis berdasarkan hasil tes kemampuan pemecahan masalah dengan data subjek secara lisan berdasarkan hasil wawancara. Data kualitatif dianalisis dengan 3 tahapan dimulai dari reduksi data, penyajian data dan menarik kesimpulan. Sedangkan data kuantitatif kemampuan subjek penelitian dalam memecahkan masalah dianalisis menggunakan program Quest dengan melihat pada nilai estimasi atau abilitas. Berikut Tabel Kriteria Kemampuan Responden berdasarkan nilai estimasi menurut Bon \& Fox (2015):

Tabel 2. Kriteria Kemampuan Responden

\begin{tabular}{cc}
\hline Nilai Estimasi & Kriteria \\
\hline Estimas $i \geq 1,00$ & Kemampuan Tinggi \\
$-1,00<$ Estimas $i<1,00$ & Kemampuan Sedang \\
Estimas $i \leq-1,00$ & Kemampuan Rendah \\
\hline
\end{tabular}




\section{HASIL PENELITIAN DAN PEMBAHASAN}

Hasil tes kemampuan pemecahan masalah yang diperoleh dianalisis menggunakan program Quest untuk mengetahui tingkat kemampuan subjek penelitian. Berikut Tabel Hasil Analisis Kemampuan Subjek Penelitian berdasarkan output program Quest :

Tabel 3. Hasil Analisis Kemampuan Subjek Penelitian

\begin{tabular}{|c|c|c|c|}
\hline NAME & I SCORE & MAXSCR & ESTIMATE \\
\hline $9 \mathrm{~A} 99$ & 5 & 525 & -1.36 \\
\hline $10 \mathrm{~A} 10$ & & 225 & -2.33 \\
\hline 11 A11 & 9 & $9 \quad 25$ & -.49 \\
\hline $12 \mathrm{~A} 12$ & 22 & 225 & 2.08 \\
\hline $13 \mathrm{~A} 13$ & 22 & 225 & 2.08 \\
\hline
\end{tabular}

Dari Tabel 3 di atas, diperoleh deskripsi kemampuan subjek dalam memecahkan masalah sebagai berikut :

Tabel 4. Deskripsi Kemampuan Subjek Penelitian

\begin{tabular}{ccc}
\hline Kode & $\begin{array}{c}\text { Nilai } \\
\text { Estimasi }\end{array}$ & Deskripsi \\
\hline A09 & $-1,36$ & Kemampuan Rendah \\
A10 & $-2,33$ & Kemampuan Rendah \\
A12 & 2,08 & Kemampuan Tinggi \\
A13 & 2,08 & Kemampuan Tinggi \\
\hline
\end{tabular}

Dalam memahami masalah memiliki kategori baik karena mampu menuliskan secara lengkap apa yang diketahui dan menjelaskan dengan tepat secara verbal anggota dari matriks A dan memahami apa yang ditanyakan pada soal tes. Hal ini senada dengan Vendiagrys (2015) yang mengemukakan bahwa subjek FI dapat memahami dan menuliskan yang diketahui dan yang ditanyakan, subjek FI cenderung menggunakan bahasanya sendiri.

Siswa yang bergaya kognitif FI mampu merencanakan strategi apa yang harus dilakukan dan rumus apa yang harus digunakan untuk menyelesaikan permasalahan pada soal tes. Subjek dengan gaya kognitif FI mampu mengorganisasikan informasi secara mandiri sehingga mampu melakukan tindakan yang mengarah pada solusi yang benar (Rusmala, 2019). Sehingga dapat dikategorikan baik dalam merencanakan penyelesaian masalah.

Dalam menyelesaikan masalah pada soal, siswa yang bergaya kognitif FI mampu menyelesaikan soal dengan menerapkan strategi yang sudah direncanakan sebelumnya, langkahlangkah penyelesaiannya pun sistematis dan tepat sesuai dengan rumus mencari determinan matriks ordo $3 \times 3$, bahkan dalam proses pengerjaannya tidak mengalami kesulitan serta teliti dalam penghitungan. Resti, Eka (2019) berpendapat bahwa siswa FI mampu menunjukan koreksi sehingga mencapai jawaban yang benar dan memiliki sifat analitik. Sehingga dapat dikategorikan baik dalam pelaksanaan penyelesaian masalah. 
Siswa yang bergaya kognitif FI mampu menuliskan dan menjelaskan hasil yang diperoleh secara tepat sesuai dengan apa yang ditanyakan pada soal, cenderung memeriksa kembali proses dan hasil penghitungannya untuk mengantisipasi adanya kesalahan pada jawaban yang diperoleh. Sehingga dapat dikategorikan baik. Subjek FI secara sadar dan berkala melihat kemajuan pemecahan masalahnya untuk mengecek proses penyelesaiannya serta menilai kerasionalan hasil akhir yang diperolehnya (Rusmala, dkk. 2019).

Siswa yang bergaya kognitif FD, dalam memahami masalah pada soal dikategorikan cukup karena mampu menulisan apa yang diketahui dan ditanyakan pada soal, namun tidak mampu menjelaskansecara lengkap dengan kalimatnya sendiri. Hal ini senada dengan pendapat Vendiagrys, Lia (2015) yaitu subjek FD cenderung berpikir secara global (menyeluruh), menerima informasi apa adanya tanpa menyesuaikan dengan bahasa matematika, subjek masih menuliskan yang diketahui dan yang ditanyakan dalam bentuk kalimat yang sama seperti dalam soal.

Siswa yang bergaya kognitif FD dikategorikan kurang karena tidak mampu menjelaskan langkah apa yang harus dilakukan untuk menyelesaikan soal yaitu tidak mengetahui bagaimana mencari determinan dari matriks A. Siswa dengan gaya kognitif FD sering mengalami kesulitan untuk mengaitkan materi yang diperolehnya untuk membuat cara baru dalam memecahkan masalah (Wulandari, 2017) sehingga rencana dan tindakan yang digunakan tidak mengarah pada solusi yang benar. Hal ini senada dengan yang dikemukakan Haryanti (2018) bahwa subjek FD menerima informasi secara global sehingga kurang mampu mengorganisasikan informasi secara mandiri dan menggunakan solusi yang kurang benar.

Siswa yang bergaya kognitif FD dikategorikan kurang karena tidak mampu dalam mengoperasikan secara tertulis dan menjelaskan proses pengerjaan mencari nilai determinan dari matriks $\mathrm{A}$ atau matriks ordo $3 \times 3$, akan tetapi subjek mampu menuliskan hasil jawaban dengan benar dikarenakan mencontek hasil pekerjaan teman sebangku.Sependapat dengan Yasa (2013) bahwa subjek FD memiliki kesulitan untuk menghubungkan konsep atau informasi yang telah ada dalam soal, tidak melakukan proses penyelesaian sesuai rencana, sehingga subjek FD mengalami kendala menemukan jawaban akhir yang benar.

Siswa yang bergaya kognitif FD dikategorikan kurang karena belum mampu memperoleh jawaban yang tepat dengan pemikirannya sendiri dan tidak menuliskan kesimpulan akhir dari masalah, serta cenderung tidak memeriksa ulang proses dan hasil pekerjaan mereka. Menurut Sasongko (2016) subjek FD tidak melakukan pengecekan pada langkah memeriksa kembali penyelesaian dikarenakan rencana yang digunakan kurang relevan

\section{KESIMPULAN}

Berdasarkan hasil dari penelitian yang telah dilakukan dapat disimpulkan bahwa siswa yang bergaya kognitif Field Independent (FI) memiliki kemampuan pemecahan masalah yang baik, dalam memahami masalah mampu menuliskan serta menjelaskan apa yang diketahui dan ditanyakan pada soal dengan kalimatnya sendiri, merencanakan penyelesaian dengan menggunakan strategi yang tepat, melaksanakan penyelesaian masalah secara sistematis dan teliti dalam penghitungan hingga memeriksa kembali jawaban yang diperolehnya, seluruh tahapan dalam memecahkan masalah dikategorikan baik. Sedangkan siswa yang bergaya kognitif Field Dependent (FD) dalam memahami masalah dikategorikan cukup karena hanya mampu menuliskan apa yang diketahui dan ditanyakan namun tidak mampu menjelaskan secara lengkap dengan kalimatnya sendiri, pada tahap merencanakan penyelesaian tidak mampu menggunakan strategi yang tepat, tidak mampu secara mandiri melaksanakan penyelesaian masalah, hingga tidak memeriksa kembali hasil pengerjaannya. Sehingga disimpulkan bahwa siswa yang memiliki tipe gaya kognitif Field Dependent hanya mampu 
sampai tahap memahami masalah dan berkategori kurang dalam merencanakan penyelesaian hingga memperoleh hasil akhir dari permasalahan.

\section{REFERENCES}

Anggraeni, R.E. (2019). Pemecahan Masalah Polya Dari Siswa SMP Bergaya Kognitif Field Dependent dan Field Independent. Journal Of The Indonesia Matematics Education Society, vol.1 (1).

Arifin. 2015. Analisis Aktifitas Metakognitif Siswa Dalam Memecahkan Masalah Matematika Ditinjau Dengan Gaya Kognitif di https://eprint.ums.ac.id (diakses 29 Mei 2019)

Athira, A.M. (2015). Analisis Kemampuan Siswa SMP Di Kota Palu Dalam Memecahkan Masalah Segiempat Berdasarkan Gaya Kognitif. Jurnal Sains dan Teknologi Tadulako, vol. 4 (1), 72 79.

BSNP. (2006). Jurnal Didaktik Matematika diakses dari https://www.jurnal.unsyiah.ac.id

Desmita.(2009). Jenis-Jenis Gaya Kognitif diakses dari https://text-id.123dok.com

Fadlillah, N. (2017). Gaya Kognitif Field Independent dan Field Dependent Siswa SMP Kelas VII dalam Memecahkan Masalah Matematika Pada Materi Segitiga Dan Segiempat Berdasarkan Gender. Vol. 1 No. 7.

Haloho, S.H. (2016). Analisis Kemampuan Pemecahan Masalah Ditinjau Dari Gaya Kognitif Siswa Pada Model Pembelajaran Missouri Mathematics Project . Skripsi . Fakultas MIPA Unnes, Semarang

Hanson. (2004). Pengaruh Model Pembelajaran Process Oriented Guided Inquiry Learning Terhadap Ketrampilan Proses Sains dan Kemampuan Kognitif Siswa Pada Mata Pelajaran Fisika diakses dari https://media.neliti.com

Hidayati, D. W. (2017). Diagnosa Kesulitan Metacognitive Awareness Terhadap Proses Pemecahan Masalah Matematika. JNPM (Jurnal Nasional Pendidikan Matematika). Vol. 1 (2), 206 - 217

Jacobsen, Eggen \& Kauchak. (2009). Upaya Meningkatkan Kemampuan Pemecahan Masalah diakses dari https://respository.upy.ac.id

Khatib, M. (2011). On the Validity Of The Group Embedded Figure Test (GEFT). Vol. 2 No. 3, pp 640648

Kusumaningtyas, S.I,. Juniati. D., \& Lukito, A. (2017). Pemecahan Masalah Generalisasi Pola Siswa Kelas VII SMP Ditinjau Dari Gaya Kognitif Field Independent dan Field Dependent. Journal Kreano, vol.8 (1).

Nuraheni, F. (2014). Keefektifan Model Process Oriented Guided Inquiry Learning terhadap Kemampuan Pemecahan Masalah. Unnes Journal Mathematics Education, vol. 3 (1).

Nurrakhmi, R.Z.F., Lukito, A. (2014). Profil Intuisi Siswa SMA Dalam Memecahkan Masalah Turunan Ditinjau Dari Gaya Kognitif Field Independent dan Field Dependent. Journal MATHEdunesa, vol.3 (3). 
Purnomo, R. C. (2017). Profil Kreativitas Dalam Pemecahan Masalah Matematika Ditinjau dari Gaya Kognitif Field Independent (FI) dan Field Dependent (FD) Siswa Kelas VIII A SMP Negeri 12 Jember. Vol. IV No. 2, 9-14

Rosidah. (2013). Keefektifan Pembelajaran POGIL Berbantu LKPD terhadap kemampuan pemecahan masalah materi pokok Peluang. Jurnal Kreano Unnes, vol. 4 (1).

Siregar, N. A. (2017). Kemampuan Pemecahan Masalah Matematis Siswa Dalam Pembelajaran Matematika Menggunakan Model Pembelajaran PBL dan TPS. Seminar Nasional Matematika. Fakultas Matematika Universitas Negeri Medan

Sugiyono. (2010). Populasi dan Sampel Penelitian diakses dari https://respository.upi.edu

Ulya, H. (2015). Hubungan Gaya Kognitif Dengan Kemampuan Siswa Pemecahan Masalah Matematika. Jurnal Konseling GUSJIGANG, vol. 1 (2).

Vendiagrys, Junaedi, Masrukan. (2015). Analisis Kemampuan Pemecahan Masalah Matematika Soal Setipe TIMSS Berdasarkan Gaya Kognitif Siswa Pada Pembelajaran Model Problem Based Learning. Unnes Journal Of Mathematics Education Research, vol. 4 (1)

Wahyuni, A. (2017). Korelasi Antara Gaya Belajar Terhadap Hasil Belajar Mahasiswa Pada Mata Kuliah Kalkulus Dasar. Jurnal Karya Pendidikan Matematika, 4 (1).

Wulandari, R. (2017). Analisis Gaya Kognitif Siswa Dalam Pemecahan Matematika Di SDN Banyuajuh 1 Kamal Madura. Widyagogik Jurnal, vol. 4, (2).

Zevenbergen. (2004). Hubungan Gaya Kognitif dengan Kemampuan Pemecahan Masalah diakses dari https://media.neliti.com 